\title{
Accounting in de "Nieuwe Economie": op zoek naar een relevantere berichtgeving?
}

Citation for published version (APA):

Vergauwen, P. G. M. C. (2001). Accounting in de "Nieuwe Economie": op zoek naar een relevantere berichtgeving? METEOR, Maastricht University School of Business and Economics. METEOR Research Memorandum No. 029 https://doi.org/10.26481/umamet.2001029

Document status and date:

Published: 01/01/2001

DOI:

10.26481/umamet.2001029

Document Version:

Publisher's PDF, also known as Version of record

\section{Please check the document version of this publication:}

- A submitted manuscript is the version of the article upon submission and before peer-review. There can be important differences between the submitted version and the official published version of record.

People interested in the research are advised to contact the author for the final version of the publication, or visit the DOI to the publisher's website.

- The final author version and the galley proof are versions of the publication after peer review.

- The final published version features the final layout of the paper including the volume, issue and page numbers.

Link to publication

\footnotetext{
General rights rights.

- You may freely distribute the URL identifying the publication in the public portal. please follow below link for the End User Agreement:

www.umlib.nl/taverne-license

Take down policy

If you believe that this document breaches copyright please contact us at:

repository@maastrichtuniversity.nl

providing details and we will investigate your claim.
}

Copyright and moral rights for the publications made accessible in the public portal are retained by the authors and/or other copyright owners and it is a condition of accessing publications that users recognise and abide by the legal requirements associated with these

- Users may download and print one copy of any publication from the public portal for the purpose of private study or research.

- You may not further distribute the material or use it for any profit-making activity or commercial gain

If the publication is distributed under the terms of Article $25 \mathrm{fa}$ of the Dutch Copyright Act, indicated by the "Taverne" license above, 


\title{
Accounting in de "Nieuwe Economie": Op Zoek naar een Relevantere Berichtgeving?
}

\author{
Dr. Philip G.M.C. Vergauwen 1 \\ MARC, Universiteit Maastricht \\ p.vergauwen@berfin.unimaas.nl
}

\author{
Dr. Sigrid N. Vandemaele $e^{\text {2 }}$ \\ ITEO, LUC Diepenbeek \\ sigrid.vandemaele@luc.ac.be
}

\author{
Februari, 2001 \\ Also published in Maandblad voor Accountancy \& Berijfseconomie, April 2001, 124-133
}

\begin{abstract}
Voor bedrijven uit de "nieuwe economie" geldt veelal dat de marktwaarde van het eigen vermogen de boekwaarde ervan in belangrijke mate overstijgt. Het overgrote deel van de waarde van het bedrijf verschijnt dus niet op de balans, met als gevolg dat de externe verslaggeving steeds minder relevante informatie aanbiedt voor de prestatiemeting en waardebepaling van het bedrijf. Wil de verslaggeving de verloren relevantie herwinnen, dan zal een bredere en vooral meer volledige rapportering over investeringen in en creatie van niet-tastbare activa gestimuleerd of zelfs verplicht moeten worden. Enkele manieren of technieken om dit te realiseren liggen reeds ter tafel maar, hoewel noodzakelijk, bestaat er nog geen concensus over algemeen aanvaarde praktijken. Dit artikel legt de pijnpunten bloot van de huidige (regelgeving omtrent) financiële verslaggeving en geeft een overzicht van actuele denkpistes om te komen tot een meer relevante verslaggeving.
\end{abstract}

\section{TREFWOORDEN: accountancy (algemeen), verslaggeving, waarderingsstelsels, wet- en regelgeving}

\section{Inleiding}

Sommige economen beweren ten stelligste dat de geïndustrialiseerde wereld zich aan het begin van een nieuwe Kondratiev lange-termijngroei cyclus bevindt. Aan het begin van een nieuwe Kondratievgolf doen zich typisch nieuwe technologieën voor die de bestaande economische structuren grondig wijzigen. De periodisering van de economische ontwikkeling toont inderdaad aan dat de uitvindingen van stoom- en dieselmachine, telefonie, luchtvaart en nieuwe energiebronnen (petroleum, elektriciteit en later kernenergie) telkens aan de basis lagen van zo'n nieuwe Kondratiev-golf. Men spreekt aan het

\footnotetext{
${ }^{1}$ Dr. Philip G.M.C. Vergauwen is Universitair Docent Management Accounting en MARC-fellow aan de Universiteit Maastricht. Hij is ook Visiting Professor aan de Flanders Business School te Antwerpen (België).
} 
begin van zo'n lange-termijngolf dan ook vaak van een "doorbraak" of een "structurele" verandering. Heden ten dage maakt vooral de term "nieuwe economie" opgang. Er is zeker nog geen consensus over een sluitende definitie van de nieuwe economie, maar over de volgende karakterisering ervan bestaat weinig twijfel. Ten eerste is er sprake van snelle technologische vooruitgang die grote onzekerheid met zich meebrengt. Ten tweede zien we een fundamentele verandering in economische activa en, daaruit volgend, een herdefiniëring van het concept "de onderneming". Ten derde ontstaan er ook nieuwe markten met nieuwe of gewijzigde eigenschappen en nieuwe relaties tussen economische agenten (Lank (1997), Zingales (2000)).

De snelle technologische vooruitgang in de informatie- en communicatietechnologie brengt onzekerheden en gevechten om de nieuwe standaarden met zich mee (Shapiro \& Varian (1999)). Nieuwe, vooral niet-tastbare activa duiken op, bijvoorbeeld informatie en intellectueel kapitaal (beide in hoofdzaak menselijk verankerd), en worden belangrijker dan tastbare activa. De positieve relatie tussen de grootte van het bedrijf en de grootte van de markt die het bedrijf kan bedienen, wordt doorbroken. Datgene wat een bedrijf tot een levensvatbaar en succesvolle onderneming maakt, verandert eveneens. De markt wordt door de toenemende en steeds makkelijker wordende globalisering steeds groter en krijgt eigenschappen die voorheen niet bestonden, zoals bijvoorbeeld schaalvoordelen aan de vraagzijde. Op deze globale markt worden nieuwe relaties leven ingeblazen, getuigen hiervan de concepten "B2B" en "B2C", "business to business" en "business to consumers". Een en ander leidt tot noodzakelijke aanpassing en verandering van bijvoorbeeld de accounting-, bedrijfsfinancierings- en investeringsaanpak. Dit artikel beoogt een analyse te geven van de veranderingen waaraan de verslaggevingsfunctie onderhevig is en legt de pijnpunten bloot van de huidige (regelgeving omtrent) de financiële verslaggeving. Deze studie geeft tevens een overzicht van actuele denkpistes om tot een relevantere verslaggeving te komen.

\section{Huidige regelgeving: niet aangepast aan gewijzigde economische structuren}

Accounting betreft in essentie periodieke verslaggeving over bedrijfsresultaten (winst- en verliesrekening) en over bedrijfsmiddelen (balans). De regels waaraan deze verslaggeving moet voldoen zijn vrij stringent (wettelijk) bepaald, gelden voor elke onderneming en hebben tot doel homogene en vooral verifieerbare informatie over het bedrijf aan te bieden aan overheid, eigenaars en andere belanghebbenden zoals werknemers en investeerders. De huidige financiële verslaggeving is in belangrijke mate retrospectief gericht en is gebaseerd op traditionele concepten als het objectiviteitsbeginsel, het voorzichtigheidsprincipe en de historische kostprijs. Dit leidt uiteraard tot problemen indien de economische structuren waarin het bedrijf opereert snel veranderen en de economische waarde van het bedrijf in toenemende mate afhangt van immateriële, minder objectief

\footnotetext{
${ }^{2}$ Dr. Sigrid N. Vandemaele is Universitair Docent Finance aan het L.U.C. Diepenbeek (België) en Fellow van
} 
meetbare factoren zoals kennis, organisatie, kwaliteit en klantenkring. Bedrijven die goed met die factoren kunnen omgaan zijn daarom veel meer waard dan uit hun balans blijkt. Bepaalde opgenomen informatie dekt niet langer meer de volledige lading, terwijl er behoefte is aan andere informatie die niet behoeft te worden gerapporteerd.

Kennis wordt steeds belangrijker, maar niet alle kennis wordt gevat in de balans. De balans weerspiegelt meestal slechts de som van de waarde van de materiële productiemiddelen. We merken derhalve een ernstig ontaarden van de statistische relatie tussen de marktwaarde van het eigen vermogen (aandeelhouderswaarde) en de boekwaarde ervan, de zogenaamde waardekloof. Indien de balans relevante én volledige informatie over de bedrijfsactiva weergaf, zouden we bijvoorbeeld een verhouding van markt- tot boekwaarde van het eigen vermogen van één verwachten: enkel dan zouden alle activa en passiva "correct" weergegeven worden in de financiële en boekhoudkundige rekeningen van het bedrijf. $\mathrm{Nu}$ zijn markt- tot boekwaardeverhoudingen groter dan één eerder regel dan uitzondering.

Voorbeeld: Markt- tot boekwaardeverhouding
Een recent onderzoek van Hoogendoorn \& de Bruijn (2000) toont aan dat de verhouding
aandeelhouderswaarde/eigen vermogen voor de vijftig grootste Nederlandse beursgenoteerde
ondernemingen in 1997 gemiddeld 5 bedraagt. Dit wil zeggen dat gemiddeld vier van de vijf guldens niet
terug te vinden zijn in de balans van de onderneming. De studie stelt ook vast dat bedrijven in de nieuwe
economie de hoogste verhouding aandeelhouderswaarde/eigen vermogen vertonen. Verder blijkt uit de
studie dat de verhouding tussen aandeelhouderswaarde en eigen vermogen in de jaren 1993 tot en met 1997
duidelijk is gestegen, namelijk van gemiddeld 2.72 tot 5.07. Er kan dus worden gesteld dat
aandeelhouderswaarde in belangrijke en toenemende mate ontleend wordt aan verwachtingen over
toekomstige winstgevendheid, zonder dat concreet identificeerbare en verhandelbare activa aanwezig zijn.
Bron: Hoogendoorn \& de Bruijn (2000)

Lev (2000) wijt de discrepantie tussen aandeelhouderswaarde en boekwaarde hoofdzakelijk aan het feit dat (1) verslaggeving vooral steunt op het herkennen van tastbare activa, (2) onzekerheid een asymmetrische behandeling krijgt doordat verwachte verliezen wel en verwachte inkomsten niet worden opgenomen en (3) enkel contracten en transacties die wettelijk verifieerbaar zijn worden opgenomen, terwijl er geabstraheerd wordt van gebeurtenissen die de waarde van de onderneming drastisch kunnen beïnvloeden, zoals bijvoorbeeld het succes van een onderzoeksproject. Het zich in hoofdzaak richten op wat tastbaar (objectief meetbaar) is enerzijds en de asymmetrische verwerking van verwachte opbrengsten en verliezen anderzijds hebben uiteraard alles te maken met het voorzichtigheidsbeginsel. Ook het zich enkel baseren op reële transacties en verifieerbare, afdwingbare contracten valt onder dit beginsel, dat vooral betrouwbaarheid en in mindere mate volledigheid beoogt.

het Instituut voor Toegepast Economisch Onderzoek (ITEO). 
In een omgeving waar het succes of het overleven van een bedrijf vooral afhangt van het engagement in onzekere projecten en van het aangaan van niet-transactiegerichte activiteiten, verliest de verslaggeving, zoals door de wet opgelegd, aan relevantie. De vraag rijst dan aan welke vereisten verslaggeving moet voldoen om die verloren relevantie terug te winnen.

\section{Een ruimere benadering van activa}

De economische theorie stelt dat de waarde van een economisch activum bepaald is door de verwachte opbrengsten die dit activum in de toekomst kan genereren. Dit inzicht is in principe opgenomen in de definitie van activa door de $\mathrm{FASB}^{3}$. Belangrijk echter is dat accountants deze definitie in de praktijk aan een hele reeks betrouwbaarheids- en verifieerbaarheidsvoorwaarden hebben onderworpen $4^{4}$ Een belangrijke voorwaarde voor registratie van een actief op de balans is dat de waarde, los van andere waarden, in monetaire eenheden te meten moet zijn. Het toepassen van de bestaande definities en criteria leidt er enerzijds toe dat intern gegenereerde 'intangibles' zelden als een actief worden opgenomen in de balans: investeringen in immateriële activa zijn namelijk tamelijk diffuus en worden meestal direct als kost ten laste van de winst- en verliesrekening gebracht. Anderzijds gebeurt de opname van 'tangibles' vaak tegen de historische kostprijs (aanschaffings- of vervaardigingsprijs), als objectieve en verifieerbare maatstaf voor waarde.

In de discussie over de relevantie van informatie vervat in de financieel-boekhoudkundige rekeningen van de onderneming moeten deze definities worden herzien. Lev (2000) stelt voor om elke restrictie betreffende betrouwbaarheid en verifieerbaarheid weg te nemen, wat de definitie van een activum zou brengen op:

".. a claim by the enterprise - not necessarily in the legal sense - to an expected benefit."

Lev (2000), p. 4

Deze wijziging zou impliceren dat alle activa, zowel materiële als (intern gegenereerde) immateriële, worden opgenomen in de balans. Tevens opent het de weg voor de registratie van een actief tegen zijn reële economische waarde, dit wil zeggen, tegen de actuele waarde van de toekomstige incrementele cash flows die gepaard gaan met dit actief (in plaats van tegen historische kostprijs).

Wanneer een actief gewaardeerd wordt tegen historische kostprijs wordt de werkelijke (economische) waarde van dat actief onderschat indien het een project met positieve netto actuele waarde (NAW)

\footnotetext{
3 “Assets are probable future economic benefits obtained or controlled by a particular entity as a result of past transactions or events ... Assets may be acquired without cost, they may be intangible, and although not exchangeable they may be usable by the entity in producing or distributing other goods or services ... legal enforceability of a claim to the benefit is not a prerequisite for a benefit to qualify as an asset ... The common characteristic possessed by all assets is "service potential" or "future economic benefit". (FASB (Financial Accounting Standards Board), 1985, Statement of Financial Accounting Concepts $N^{0}$. 6, Elements of Financial Statements, §§ 25-28)

4 "To be recognised as assets in financial reports, information about the existence and amount of an asset, liability, or change therein must be reliable, i.e. representationally faithful, verifiable and neutral. Reliability may affect the timing of recognition of assets. The first available information about an event that may have resulted in an asset, ... is sometimes too uncertain to be recognised: it may not yet be clear whether the effects of the events (e.g. R\&D investment) meet one or more of the definitions or whether they are measurable, and the cost of resolving
} 
betreft. De investeringsleer definieert de NAW als het verschil tussen de actuele waarde van de incrementele toekomstige cash flows gegenereerd door het project en de huidige, meestal negatieve, cash flow (= initiële investering, 'historische kostprijs') die gepaard gaat met het project. De investeringsleer stelt verder dat, indien het bedrijf maximale waardecreatie voor de aandeelhouders als doel heeft, enkel projecten met positieve NAW dienen te worden ondernomen. Indien een bedrijf waardecreatie als doelstelling hanteert en de activa in de balans registreert tegen historische kostprijs, dan volgt daaruit dat de boekwaarde van de activa beneden de economische waarde ligt. Het creëren van en sturen op aandeelhouderswaarde wordt van steeds meer belang geacht (zie ook Hoogendoorn \& de Bruijn (2000)). Getuigen daarvan concepten als "Value-Based Management (VBM)", "Economic Value Added (EVA)" en "Shareholder Value Added (SVA)". Het toenemend belang dat gehecht wordt aan creatie van aandeelhouderswaarde kan mede een verklaring zijn voor de groeiende discrepantie tussen boek- en marktwaarde.

Indien de activa tegen reële waarden (in plaats van tegen historische kostprijs) werden gewaardeerd, zou een deel van de waardekloof worden gedicht. Het voorstel is dus om van een retrospectief comptabel model naar een meer prospectief comptabel model over te stappen. Recent werd een stap in die richting gezet door het IASC ${ }^{\text {[ }}$. De IASC introduceerde namelijk in maart 1999 de toepassing van reële waarde (fair value) voor de behandeling van financiële instrumenten in de financiële verslaggeving (IAS 39). In Brussel wordt gewerkt aan een wijziging van de EU Richtlijnen teneinde onverenigbaarheid met IAS 39 weg te werken. Volledigheidshalve moet worden gezegd dat een prospectief model nog niet aan de orde is voor materiële en immateriële activa. De vrees is dat de waardemaatstaf in belangrijke mate subjectief wordt, daar het bepalen van reële waarden in het geval van materiële en immateriële activa gepaard gaat met een groot aantal veronderstellingen. In het rapport van het Nederlandse Ministerie van Economische Zaken (1999) wordt gesteld dat subjectiviteit op zich geen probleem hoeft te zijn, mits de waardering als betrouwbaar kan worden aangemerkt (zie rapportage door Moret Ernst \& Young). Deze afweging tussen objectiviteit en relevantie wordt vaak verwoord in de bekende uitspraak: 'het is beter om ongeveer juist te zijn dan precies fout'.

Een deel van de waardekloof is te wijten aan het te laag waarderen van activa; een ander deel wordt veroorzaakt door het niet in de balans opnemen van (intern gegenereerde) immateriële vaste activa (Hoogendoorn \& de Bruijn (2000)). Vele immateriële productiemiddelen, zoals intellectueel kapitaal, doorstaan de test van voldoende identificeerbaarheid en betrouwbaarheid niet en worden derhalve niet op de balans opgevoerd.

Ervan uitgaande dat in de technologie- en kennisintensieve nieuwe economie het intellectueel kapitaal één van de belangrijkste factoren is in de strijd om het creëren en behouden van een competititief

those uncertainties may be excessive". (FASB, 1984, Statement of Financial Accounting Concepts $\mathrm{N}^{0}$. 5, Recognition and measurement in Financial Statements of Business Enterprises, §§ 75-76)

${ }^{5}$ Voor onderhavig vraagstuk is vooral de regelgeving in IASC verband van belang daar internationaal de verslaggeving ertoe lijkt te convergeren. De belangrijkste ontwikkeling is hier ongetwijfeld het gezamenlijk pogen van de beurstoezichthouders, verenigd in IOSCO, om althans voor 'cross border listings' tot een eensluidende set van normen te komen. Men maakt hierbij gebruik van de IAS. Sinds de Europese 
voordeel, is degelijke verslaggeving erover broodnodig. Onder intellectueel kapitaal wordt verstaan (1) menselijk kapitaal, (2) structureel kapitaal en (3) relationeel kapitaal. Onder menselijk kapitaal worden de kennis, kunde en ervaring van de medewerkers en het management bedoeld, vervat in concepten zoals bijvoorbeeld ideeën-, leiderschaps- en innovatiekapitaal (Johnson (1999)). Het structureel kapitaal betreft datgene wat de organisatiestructuur tot competitief voordeel voor de onderneming maakt (onder meer organisatiecultuur, maar ook patenten, auteursrechten en dergelijke vallen hieronder). Relationeel kapitaal betreft de unieke relaties die het bedrijf onderhoudt met klanten, leveranciers en aandeelhouders, en mogelijkerwijze zelfs met concurrenten.

Geen van de drie concepten ziet zich echter adequaat vertaald in de verslaggeving van de onderneming. Meerdere instanties kwamen in het verleden tot de conclusie dat het opnemen van kennis in de balans niet realistisch is, maar dat een bijlage bij het jaarverslag tot de mogelijkheden behoort (zie de reeds aangehaalde studie van het Ministerie van Economische Zaken voor een overzicht). Dus informatie over kennis zou - bij voorkeur - verstrekt worden in niet-comptabele (retrospectieve of prospectieve) vorm ${ }^{6}$. Dit is een terrein dan niet bestreken wordt door de jaarrekening in enge zin, maar door het jaar- of directieverslag. De keuze voor de niet-comptabele vorm is gebaseerd op de vaststelling dat de meeste wetgevingen bepaald niet uitnodigen tot het activeren van dergelijke activa en op de inschatting dat de piste van wetswijzigingen te veel tijd in beslag zou nemen of gewoonweg niet haalbaar is. De regelgeving voor niet-comptabele informatie daarentegen is aanzienlijk beperkter ${ }^{7}$ Evenwel moet opgemerkt worden dat het belang van de balans als indicator voor waardebepaling ten gevolge van de keuze voor niet-comptabele informatie over intellectual capital niet toeneemt.

Uit de praktijk blijkt dat bedrijven reeds hun heil zoeken in niet-comptabele informatie: de ruimte in het jaarverslag toebedeeld aan intellectueel kapitaal neemt immers toe. Een trendsetter op dit vlak is ongetwijfeld de Zweedse Skandia Bank. Sinds 1993 voorziet deze onderneming in een vrij omvangrijke supplement ("Balanced Annual Report on Intellectual Capital") van het jaarverslag de geïnteresseerde van belangrijke informatie over menselijk kapitaal als "activum” (Lynn (1998), Edvinsson (1997), Skandia AFS (1993)).

Het kwantificeren van intellectueel kapitaal noodzaakt meetbare indicatoren. Deze problematiek is uitgegroeid tot een interdisciplinair onderzoeksdomein. (Voor een bondig overzicht zie onder meer Bontis (1999), Bassi \& Van Duren (1999), Lynn (1998), Masoulas (1999) en Johnson (1999)). Voorbeelden van (geaggregeerde) evaluatiemethoden voor intellectueel kapitaal zijn o.a. "Calculated Intellectual/Intangible Value" (Stewart (1995)) en de "Strassman" methode (Bontis et al. (1999).) Ook de reële-optietheorie verschaft nuttige inzichten wanneer het erop aankomt intangibles te meten.

Commissie in het kader van haar nieuwe 'accounting policy'(1995) zich bij deze ontwikkeling heeft aangesloten vormen de IAS ook de leidraad voor de verdere ontwikkelingen in de meeste Europese landen.

${ }^{6}$ Niet-comptabele informatie staat tegenover comptabele informatie. Comptabele informatie is informatie die wordt gegoten in de vorm van een comptabel verband uitmondend in een samenhangend geheel van vermogen en resultaat, uitgedrukt in geld (Ministerie van Econnomische Zaken (1999)). 
Voorbeeld: Intellectueel kapitaal: CIV

Eén manier om tot een geaggregeerde berekening te komen van intellectueel kapitaal is nauw verwant aan het berekenen van de merknaamwaarde. Onderzoekers van de Kellog Business School van de Northwestern University in Chicago stellen de "Calculated Intellectual/Intangible Value" (CIV) voor en berekenen deze op de volgende manier:

- Stap 1: Bereken de gemiddelde winst voor belasting over de laatste drie of vijf jaar.

- Stap 2: Bereken de gemiddelde waarde van de tastbare activa aan het einde van het boekjaar voor diezelfde periode.

- Stap 3: Deel het getal berekend in de eerste stap door dat in stap twee, i.e., bereken de ROA.

- Stap 4: Bereken eveneens de gemiddelde ROA voor de bedrijfstak, uiteraard voor dezelfde periode.

- Stap 5: Vermenigvuldig het bedrijfstakgemiddelde met de berekende gemiddelde van de tastbare activa van de onderneming en trek daarvan het getal verkregen in de eerste stap af.

- Stap 6: Bereken de gemiddelde belastingsvoet en vermenigvuldig deze met het getal uit stap 5. Doe hetzelfde voor de rendabilitieit na belasting en bereken het verschil en men krijgt met name de "premie" van niet-tastbare activa.

- Stap 7: Bereken de netto actuele waarde van de premie uit stap 6 aan de hand van de kapitaalkosten van de onderneming.

Bron: Stewart (1995)

Voorbeeld: Intellectueel kapitaal: Strassman's method

De waarde van het kenniskapitaal van de onderneming wordt berekend als de ratio van de "door het management toegevoegde waarde" en de prijs van het kapitaal. De door het management toegevoegde waarde betreft in essentie de winst na belasting minus de (aandeelhouders-)kapitaalkosten. Deze methode is eveneens erg geaggregeerd en kan elke niet-tastbaar activum naar waarde schatten. Het betreft hier dan ook slechts een benadering van het intellectueel kapitaal van de onderneming.

Bron: Bassi \& Van Buren (1999)

De bovenvermelde onderdelen van intellectueel kapitaal kunnen ook op kwalitatieve wijze worden gemeten. Wat het menselijk (ideeën-)kapitaal betreft, stelt Johnson (1999) bijvoorbeeld maatstaven voor zoals het aantal ideeën en de fractie daarvan dat daadwerkelijk wordt geïmplenteerd. Voor structureel kapitaal kunnen interne enquetes die praktijken en procedures binnen de onderneming beschrijven belangrijke kwalitatieve indicatoren zijn (zie onder meer de Balanced Scorecard), terwijl voor relationeel kapitaal het aantal allianties, of het aantal klanten dat herhaaldelijk aankoopt (maatstaf voor klantentrouw) belangrijke maatstaven zijn. Ook in het pilootproject "Balancing Accounts with Knowledge" (Ministerie van Economische Zaken (1999)), kiezen de consultants (KPMG, ME\&Y, PwC en Walgemoed) voor methodes die nauw verwant zijn aan de Balanced Scorecard benadering. Wetenschappelijk onderzoek heeft herhaaldelijk aangetoond dat niet-financiële maatstaven "leading indicators" zijn van de bedrijfsprestaties zoals vertaald in financiële verslaggeving (zie Amir \& Lev (1996) en Hand (2000)). Meer specifiek tonen Brooking, Board \& Jones (1998) aan dat kwalitatieve maatstaven van intellectueel kapitaal analoog aan een combinatie van de indicatoren zojuist besproken inderdaad voorspellend potentieel hebben.

\footnotetext{
${ }^{7}$ Het IASC heeft zich op dit laatste terrein nog nauwelijks begeven, de EU Richtlijnen en de Nederlandse wetgeving bevatten uiterst globale aanwijzingen.
} 


\section{Een andere houding ten opzichte van onzekerheid}

Het concept onzekerheid dient op een veel ruimere en meer economisch relevante wijze te worden geïntegreerd in de financiële overzichten. Traditioneel gaat accounting ervan uit dat onzekerheid dient te worden vermeden omdat dit de betrouwbaarheid van de verslaggeving ondermijnt. Indien onzekerheid niet kan worden vermeden, gebiedt een conservatief ("goed") bestuur op zijn minst een adequate indekking (hedging). De ondernemer, daarentegen, ziet in onzekerheid vaak een kans die het bedrijf in de toekomst belangrijke opbrengsten kan opleveren.

Om onzekerheid op een relevante manier te integreren in de verslaggeving is er behoefte aan een fijnere benadering van onzekerheid en risico. De reële optietheorie verschaft hieromtrent waardevolle inzichten, stellende dat bepaalde uitgaven gerechtvaardigd kunnen zijn vanwege de opties (“opportunities") die ze creëren in de toekomst.

Voorbeeld: Reële-Optietheorie (1)

Een risicovol onderzoeks- en ontwikkelingsproject zou op een economisch relevantere wijze geëvalueerd kunnen worden door de investering te bezien als het verwerven van een recht om tegen een vooraf bepaalde prijs (uitoefenprijs) eigenaar te worden van de opbrengsten gegenereerd door de onderliggende nieuwe technologie ("call-optie"). Het initieel vereiste kapitaal is dan de prijs van de optie, terwijl de uitoefenprijs gelijk is aan het kapitaal dat nodig is om tot productontwikkeling en commercialisatie over te gaan van zodra het succes van het initiële project is bewezen. Indien succes in de initiële onderzoeksfase uitblijft, is de optie uiteraard "out of the money" en dus waardeloos.

Wanneer uitgaven voor onderzoek en ontwikkeling $(\mathrm{O} \& \mathrm{O})$ niet geactiveerd worden wegens onzekere toekomstige opbrengsten, worden impliciet twee veronderstellingen gemaakt, namelijk (a) dat de gedane uitgaven niet kunnen worden gerecupereerd en (b) dat er geen opties worden gecreëerd door het doen van deze O\&O uitgaven. Waar in vele gevallen de eerste veronderstelling aanvaardbaar en zelfs gerechtvaardigd is ("sunk costs"), is dit veel minder het geval voor de tweede veronderstelling. O\&O investeringen worden veelal ondernomen juist omwille van hun 'strategische waarde', waarmee de opportuniteiten of opties worden bedoeld die deze met zich meebrengen.

In het geval een bedrijf een niet recupereerbare O\&O uitgave doet waarvan men geen weerslag vindt in de balans, negeert de financiële verslaggeving de waarde van de opties die een dergelijke investering met zich meebrengt. Nu leert de reële-optietheorie ons dat de waarde van de mogelijkheid een project uit te voeren (a) groter is dan de NAW van het onderliggend project en (b) toeneemt naarmate de onzekerheid omtrent het onderliggend project (opbrengsten en/of kosten) stijgt. De intuitie is dat wanneer managers nog de keuze hebben tussen het al dan niet uitvoeren van een project - in tegenstelling tot gecommitteerd zijn tot - een eenzijdige pay-off mogelijk wordt (waarbij slechte uitkomsten vermeden worden). De waarde van deze keuzemogelijkheid (versus commitment) neemt uiteraard toe naarmate de onzekerheid omtrent het onderliggend project stijgt. 
Voorbeeld: Reële-Optietheorie (2)

Een bedrijf kan een marktonderzoek laten uitvoeren om na te gaan in hoeverre voor een nieuw product een markt bestaat. De kosten van dit onderzoek bedragen Hfl. 1 miljoen. Indien deze initiële test positief is (a priori kans wordt op 50\% geschat), wordt de NAW van de productie- en marketingfase op Hfl. 4 miljoen geschat. In het andere geval wordt de NAW van de productie- en marketingfase op Hfl. -4 miljoen geschat. De huidige beslissing $(\mathrm{t}=0)$ betreft het al dan niet laten uitvoeren van het marktonderzoek. Wanneer duidelijk is of al dan niet een markt bestaat $(t=1)$, volgt een tweede beslissing: het al dan niet doorgaan met de productie- en marketingfase. Indien het project wordt geanalyseerd zonder rekening te houden met de mogelijkheid van nietuitvoering ervan binnen een jaar, dan zal het niet worden ondernomen. Immers, de huidige waarde van de verwachte NAW van het project is nul (verdisconteerd tegen welke kapitaalkosten dan ook). Het management zal zeker niet bereid zijn Hfl. 1 miljoen te spenderen voor een project met een verwachte netto actuele waarde van nul. Echter, dit is een misspecificatie van de investeringsopportuniteit. Omdat het management het recht heeft en niet de verplichting de productie- en marketingfase te ondernemen, zijn de mogelijke payoffs volgend jaar een NAW van Hfl. 4 miljoen indien de initiële markttest positief is, en een NAW van Hfl. 0 indien de test negatief is (de productie- en marketingfase worden in dit geval niet uitgevoerd en de optie is waardeloos). Deze payoff-distributie heeft een verwachte waarde van Hfl. 2 miljoen. Zolang de kapitaalkosten waartegen het project verdisconteerd wordt minder bedragen dan $100 \%$ per jaar, zal de huidige waarde van de verwachte NAW van het project hoger zijn dan de huidige kosten van Hfl. 1 miljoen van het marktonderzoek. Bovenstaand voorbeeld illustreert dat de mogelijkheid een project uit te voeren (eerder dan een verplichting) extra waarde creëert.

Aan de hand van bovenstaand voorbeeld kan ook de impact van onzekerheid op de NAW van het project onderzocht worden. Veronderstel dat het interval van mogelijke uitkomsten verdubbelt terwijl de verwachte waarde nul blijft: Hfl. 8 miljoen indien het marktonderzoek een succes is en Hfl. -8 miljoen indien niet. Omdat het management de productie- en marketingfase niet gaat ondernemen indien het initiële marktonderzoek negatief is, is de slechtst mogelijke payoff nog steeds 0 en niet -8 miljoen. Bijgevolg stijgt de verwachte NAW binnen een jaar van Hfl. 2 miljoen tot Hfl. 4 miljoen. De verwachte NAW van het project verdubbelt dus als een gevolg van de verdubbeling van het interval van de mogelijke payoffs. Het is in deze zin dat een toename van de onzekerheid omtrent de toekomstige payoffs verbonden aan een project leidt tot een stijging in de waarde van het project.

Het is een eigenschap van de nieuwe economie dat een toenemend deel van de bedrijfswaarde gebaseerd is op 'intangibles' in de vorm van toekomstige opties. De nieuwe economie brengt ook toenemende onzekerheden met zich mee. Het niet registreren van de waarde van deze opties in de financiële overzichten van bedrijven in het tijdperk van de nieuwe economie leidt bijgevolg tot toenemende irrelevantie van de financiële verslaggeving.

\section{Een weergave van het volledige bedrijfsproces}

Zoals reeds werd gezegd, komt een belangrijk deel van de economische waarde van een onderneming in de nieuwe economie voort uit niet-transactiegebonden activiteiten of processen. Twee voorbeelden van zulke processen betreffen het innovatie- en het daaraan nauw gerelateerde networking- en informatieuitwisselingsproces. De schaalvoordelen aan de vraagzijde in de nieuwe economie illustreren hoe ook de eigenschappen van de markt(en) waarop de onderneming actief is, van groot belang zijn voor de waarde van die onderneming.

Het verdient aanbeveling alle lopende en geplande investeringen in fasen op te delen (zoals dat reeds gebeurt voor het management ervan) en aan deze verschillende fasen ook verschillende 
verslaggevingsvereisten te stellen. Verschillende investeringen in verschillende fasen zouden dan als dusdanig onderscheiden kunnen worden in de externe verslaggeving. De innovatieketen zou, met andere woorden, op veel minder geaggregeerde wijze voorgesteld kunnen worden. Fundamentele fasen in deze innovatieketen zijn (1) het ontdekkings- en leerproces, (2) het implementatieproces en (3) het ontwikkelings- en commercialisatieproces. Elk van deze fasen heeft uiteraard een verschillend risicokarakter en, belangrijker nog, brengt een verschillende behoefte aan informatie met zich mee. De huidige regelgeving met betrekking tot rapportage van bedrijfsprestaties zorgt niet voor tijdige en relevante informatie, juist omdat zulke investeringen op te geaggregeerde en dus te weinig gedifferentieerde manier worden weergegeven. Nochtans is elke fase van de innovatieketen cruciaal in het al dan niet succesvol zijn of overleven van het bedrijf. Een voorstel zou kunnen zijn om de investeringen in de eerste fase (ontdekkings- en leerfase) onmiddellijk als uitgaven te boeken, omwille van hun "sunk-cost"-karakter, en dus omwille van de onomkeerbaarheid. Met andere woorden, omdat dit uitgaven betreft die, eenmaal gedaan, niet gerecupereerd kunnen worden. Uitgaven in infrastructuur die nodig zijn voor in de implementatie- en, a fortiori, commercialisatiefase zijn veel minder onomkeerbaar of beter recupereerbaar, en behoeven aldus niet volledig als uitgave in de financiële rekenigen van de betreffende periode te worden geboekt.

Traditioneel als niet relevant voor de verslaggeving beschouwd, maar meer dan ooit van cruciaal belang voor de onderneming, zijn samenwerkingsakkoorden of allianties en intranetsystemen ter bevordering van de informatie-uitwisseling. Een bedrijf kan actief zijn op - vaak informele - markten voor niet-tastbare activa, zoals bijvoorbeeld menselijk (intellectueel) kapitaal (Teece (1998b), of een belangrijke niet-contracteerbare verstandhouding met leveranciers of consumenten hebben die van groot belang voor het succes van de onderneming (Lev (2000)). In economische termen spreekt men in zulke gevallen vaak van competitieve voordelen, die voor het bedrijf in kwestie een echt economisch activum vormen maar die niet vertaald worden in de boekhouding. Neem bijvoorbeeld e-commerce. In de meeste periodieke verslagen van ondernemingen wordt niet vermeld welk deel van de omzet of winst nu behaald wordt via e-commerce, terwijl dit aandeel een belangrijke maatstaf is voor de huidige en toekomstige prestatie van het bedrijf, zeker indien de aanwezigheid van dat bedrijf op de digitale markten een noodzaak is voor overleven.

De link met de aanwezige - en voor de nieuwe economie cruciale - schaalvoordelen aan de vraagzijde kan hier worden gelegd. Schaalvoordelen aan de vraagzijde kunnen op verschillende wijzen geïnterpreteerd worden naar analogie met productieschaalvoordelen. Productieschaalvoordelen houden in dat de kosten per eenheid productie bij stijgende productie. Schaalvoordelen aan de vraagzijde houden dan in dat, hoe meer er van het product al verkocht is, hoe sterker de vraag ernaar zal worden. Met andere woorden, steeds meer mensen zullen bereid zijn om meer te betalen voor het product indien het aantal gebruikers van het product toeneemt. Twee voorbeelden zijn het integreren van verschillende producten tot één nieuw product enerzijds, en de netwerkingeffecten tussen de kopers van het product anderzijds. 
Voorbeeld: Schaalvoordelen aan de vraagzijde (1)

Consumenten zijn bereid meer te betalen voor een toestel dat het mogelijk maakt een boek te bestellen via het internet op de trein van en naar het werk. Dit houdt in dat iemand die daar prijs op stelt, bereid is meer te betalen voor een laptop die via infrarood straling de verbinding maakt met een mobiel telefoontoestel en die bestelling kan overmaken aan een dot.com-bedrijf, dan hij bereid is te betalen voor een mobiel telefoontoestel plus laptop plus internettoegang via provider plus registratie bij dat dot.com-bedrijf. Het boek dat hij op die manier koopt heeft economisch gezien totaal verschillende eigenschappen dan dat zelfde boek dat hij koopt in een boekenwinkel in Amsterdam tijdens een dagje uit in Nederlands hoofdstad. Men zou kunnen zeggen het boek dat hij on-line koopt alle eigenschappen van de tchnologie die hij daartoe gebruikt overneemt.

Voorbeeld: Schaalvoordelen aan vraagzijde (2)

Een tweede voorbeeld is de waarde die iemand hecht aan de mogelijkheid om via internet tweedehands boeken te kopen. De (meer)waarde die iemand hecht aan het feit dat er iemand in Japan dezelfde auto koopt mag dan al (bijna) nihil zijn, de waarde die hij of zij eraan hecht om meer mede-consumenten op de tweedehandsmarkt aan te treffen, is bijzonder groot. De kans dat hij of zij een bepaald boek tweedehands vindt is immers recht evenredig met het aantal mogelijke verkopers van tweedehands boeken, met andere woorden, met het aantal potentiële andere klanten van hetzelfde product.

De economische waarde voor de onderneming van deze potentiële schaalvoordelen wordt niet of onvoldoende weergegeven in de verslaggeving, terwijl bepaalde "uitgaven" om dit te bewerkstelligen wel worden opgenomen, maar worden losgekoppeld van de mogelijke "inkomsten" die daaruit (kunnen) voortvloeien.

Belangrijke, toekomstgerichte informatie over de prestatie van een bedrijf in de nieuwe economie wordt aldus niet opgenomen in de verslaggeving, of, indien wel opgenomen, op een veel te weinig genuanceerde of gedifferentieerde manier.

\section{Naar een convergentie van interne en externe verslaggeving?}

In de nieuwe economie hebben managers behoefte aan een nieuw besturingsinstrumentarium. Dit instrumentarium moet transparantie verschaffen over de kwaliteit en de waarde van de immateriële productiemiddelen en hun potentie voor de toekomst.

Uit de studie in opdracht van het Ministerie van Economische Zaken (1999) kwam naar voren dat de bedrijven vooral het nut inzien van instrumenten voor immateriële productiemiddelen ten behoeve van de interne sturing van het management. Een goed inzicht in de inspanningen die gedaan worden in de sfeer van O\&O, opleidingen, marktonderzoeken, software etc. is belangrijk als intern sturingsmiddel voor het management. Belangrijk in deze context is op zoek te gaan naar de drijvende krachten van intellectueel kapitaal zodat kan worden nagegaan hoe en in welke mate deze niet-tastbare activa en het management ervan het ondernemingsresultaat beïnvloeden. Zodoende krijgt het management een beter inzicht in het belang en de werking van intellectueel kapitaal en kan dit kapitaal gemeten (gekwantificeerd) worden. Op zijn beurt kan dit hen in staat stellen een financieel-boekhoudkundige 
waarde toe te kennen aan deze activa of deze activa op meer een relevante en accurate wijze in de externe verslaggeving te introduceren.

Uit de rapportages door de vier consultants (KPMG, ME\&Y, PwC en Walgemoed) in de studie van het Ministerie van Economische Zaken (1999) blijkt ook duidelijk dat het begaan van nieuwe wegen inzake externe verslaggeving alleen mogelijk is als dit een fundament vindt in de interne verslaggeving. De expertise die binnen de onderneming beschikbaar is blijkt onmisbaar om tot verantwoorde informatie te komen. Zowel het bepalen van relevante prestatie-indicatoren in de nietcomptabele sfeer als het afgrenzen van bruikbare "intangibles" in de comptabele sfeer blijft maatwerk. Indien de regelgeving voor de externe verslaggeving zou worden ingezet voor het bevorderen van transparantie zal deze voldoende ruimte moeten laten voor een ondernemings- of ten minste bedrijfstak-specifieke aanpak.

Belangrijke inzichten kunnen tot stand komen door het management-controlsysteem binnen de onderneming te bestuderen in bijvoorbeeld het innovatie- of productontwikkelingsproces. Een onderneming die op de meest efficiënte en effectieve wijze nieuwe producten op de markt wil brengen, zal willen weten welke informatie en welk daarop gebaseerd managementsysteem tot het beste resultaat kan leiden (zie ook Vergauwen (2000)). De onderneming zal dus trachten na te gaan welke activiteiten moeten worden aangemoedigd of ontmoedigd en wat de functie is van bepaalde activiteiten in het creëren van toegevoegde waarde. Davila (2000) toont aan dat betere kosten- en designinformatie leiden tot betere prestaties, en stelt drie maatstaven voor het bepalen van de informatie-inhoud van management-controlsystemen voor. Daaruit blijkt dat zulke systemen inderdaad informatie genereren die belangrijk is voor het bepalen van de toekomstige ondernemingsprestatie.

Opgemerkt moet worden dat sommige ondernemingen een grote terughoudendheid vertonen voor het openbaar maken van dergelijke informatie omdat deze de kern van de strategie van een onderneming raken en sterke en zwakke punten blootleggen.

Hoewel de drijvende krachten achter het ontwikkelen van nieuwe methoden omtrent de verwerking van immateriële productiemiddelen in de jaarverslaggeving momenteel nog voornamelijk van bedrijfsinterne oorsprong zijn, moet niet worden uitgesloten dat in de komende jaren de druk van externe partijen tot openbaarmaking verder zal toenemen.

\section{Onderzoeksagenda en conclusies}

Dit artikel duidt de opname tegen historische kostprijs in plaats van tegen reële waarde en het niet opnemen van belangrijke waardescheppende (intern gegenereerde) productiemiddelen als voornaamste oorzaken van de waardekloof. Om de waardekloof te dichten worden een twee voorstellen geformuleerd. Ten eerste wordt gepleit voor de overgang van een louter retrospectieve verslaggeving naar een verslaggeving die meer gebaseerd is op prospectieve informatie. Ten tweede wordt, met betrekking tot de niet-identificeerbare immateriële activa, gepleit voor het verschaffen van niet- 
comptabele informatie. Een aantal meetbare indicatoren of meer kwalitatieve maatstaven van intellectueel kapitaal die recent hun ingang hebben gevonden in de literatuur en/of praktijk werden in dit verband besproken.

Deze studie suggereert dat de opstellers van financiële cijfers een meer actieve rol moeten gaan spelen in de communicatie van de onderneming en de traditionele informatieset waarmee ze werken, verruimen (onder meer met management informatie), indien de verslaggevingsfunctie niet alle relevantie wil verliezen. Dit zal zeker het geval zijn indien de managementwetenschappen tot nieuwe inzichten komen met betrekking tot intellectueel kapitaal. Het accurater kunnen meten, beter evalueren en beheren van dit kapitaal, dat - zoals reeds herhaalde malen gesteld - een belangrijk activum voor de onderneming in de nieuwe, kennis- en technologie-intensieve economie vormt, kan inderdaad aanleiding geven tot (1) het beter organiseren van alle activiteiten die voor het genereren van toegevoegde waarde (en dus voor het lange-termijnperspectief) van de onderneming van essentieel belang zijn, en tot (2) een meer relevante verslaggeving die hetzij voorheen nauwelijks gekwanticifeerde informatie, hetzij niet-financiële informatie kan opnemen ten behoeve van alle belanghebbenden.

Verder onderzoek op dit gebied, zal (1) multidisciplinair moeten zijn om in staat te zijn inzichten uit de "human resource"-, kennismanagement- en management-controlliteratuur te integreren, en (2) "nieuwe" onderzoeksmethoden moeten introduceren die traditioneel niet tot de "toolbox" van de accountant of financieel verantwoordelijke behoren. Zoals Lev (2000) stelt, zal het maken van een nieuwe blauwdruk voor verslaggeving in de nieuwe economie een meer experimentele, door interviews en observaties gecomplementeerde aanpak vereisen en gebruik moeten maken van een vooral inductief en empirisch ondersteund denkkader voor verandering dat niet vreemd kan zijn aan het "entrepreneurial" gedachtengoed. Dit alles volgt uit de vaststelling dat in de nieuwe economie de belangrijkste informatie over de ondernemingsprestaties niet langer gebaseerd is op transacties (uitwisselingen van eigendomsrechten), maar op veel minder in accountingconcepten te vatten activiteiten. Alleen indien zulke activiteiten zich toch op de een of andere manier in de balans en de rekeningen van de onderneming vertaald zien, zullen balans en financiële rekeningen verloren relevantie herwinnen. Om dit alles te bewerkstelligen is echter meer onderzoek naar het meten, evalueren en begrijpen van kenniskapitaal nodig.

\section{Literatuurlijst}

Amir, E. \& B. Lev, 1996, Value-Relevance of Non-Financial Information: The Wireless Communications Industry, Journal of Accounting and Economics 22, 3-30

Bassi, L.J. \& M.E. Van Buren, 1999, Valuing Investments in Intellectual Capital, International Journal of Technology Management 18 (5-8), 414-432

Bontis, N., 1999, Managing Organisational Knowledge by Diagnosing Intellectual Capital: Framing and Advancing the State of the Field, International Journal of Technology Management 18 (5-8), 433-462 
Bontis, N., N.C. Dragonetti, K. Jacobsen \& G. Roos, 1999, The Knowledge Toolbox: A Review of the Tools Available to Measure and Manage Intangible Resources, European Management Journal 17(4), 391402

Brookings, A., P. Board \& S. Jones, 1998, The Predictive Potential of Intellectual Capital, International Journal of Technology Management 16 (1-3), 115-125

Davila, T., 2000, An Empirical Study on the Drivers of Management Control Systems' Design in New Product Development, Accounting, Organisations and Society 25, 383-409

Dixit, A.K. \& R.S. Pindyck, 1994, Investment Under Uncertainty, Princeton University Press, Princeton (NJ), $468 \mathrm{p}$.

Edvinsson, L., 1997, Developing Intellectual Capital at Skandia, Long Range Planning 30(3), 366-373

Hand, J.R., 2000, Profits, Losses and the Non-linear Pricing of Internet Stocks, Kenan-Flagler Business School, UNC Chapel Hill (NC), working paper, 47p.

Hoogendoorn, M.N. \& S.M.M. de Bruijn, 2000, De Kloof Tussen Aandeelhouderswaarde en Eigen Vermogen: Omvang, Oorzaken en Oplossingen, Tijdschrift voor Bedrijfsadministratie vol. 104(1233), 206-214

Johnson, W.H.A., 1999, An Integrative Taxonomy of Intellectual Capital: Measuring the Stock and Flow of Intellectual Capital Components in Firms, International Journal of Technology Management 18 (5-8), $562-575$

Lev, B., 2000, New Accounting for the New Economy, Stern School of Business, New York University (NY), working paper, $27 \mathrm{p}$.

Lev, B., 1996, The Capitalisation, Amortisation and Value-Relevance of R\&D, Journal of Accounting and Economics 21, 107-138

Lank, E., 1997, Leveraging Invisible Assets: the Human Factor, Long Range Planning vol. 30(3), 406-412

Luehrman, T.A. , 1998, Strategy as a Portfolio of Real Options, Harvard Business Review, September-October, 89-99

Luehrman, T.A. , 1998, Investment Opportunities as Real Options: Getting Started on the Numbers, Harvard Business Review, July-August, 51-67

Lynn, B., 1998, Performance Evaluation in the New Economy: Bringing the Measurement and Evaluation of Intellectual Capital into the Management Planning and Control System, International Journal of Technology Management 16 (1-3), 162-176

Masoulas, V., 1998, Organisational Requirements Definition for Intellectual Capital Management, International Journal of Technology Management 16 (1-3), 126-143

Ministerie van Economische Zaken Nederland, 1999, Balancing Accounts with Knowledge, Pilot Project of the Dutch Ministry of Economic Affairs, Directorate-General for Economic Structure, Technology Policy Department

Rennie, M., 1999, Accounting For Knowledge Assets: Do We Need a New Financial Statement?, International Journal of Technology Management 18 (5-8), 648-659

Sercu, P. \& C. Van Hulle, Traditionele versus optie-waarderingsmethodes voor groeibedrijven: er zijn geen mirakeloplossingen, Tijdschrift voor Economie en Management 44 (3), 323-336

Shapiro, C. \& H.R. Varian, 1999, Information Rules, Harvard Business School Press, Boston (MA), 352p.

Stewart, T.A., 1995, Trying to Grasp the Intangible, Fortune (Oct. $2^{\text {nd }}$ ), Chicago

Teece, D.J., 2000, Strategies For Managing Knowledge Assets: The Role of Firm Structure and Industrial Context, Long Range Planning 33, 35

Teece, D.J., 1998, Capturing Value From Knowledge Assets: The New Economy, Markets For Know-How and Intangible Assets, California Management Review 40(3), 55-79

Teece, D. J., 1998, Research Directions for Knowledge Management, California Management Review 40(3), 289-292

Vergauwen, P.G.M.C., 2000, Ondernemerschap en Ondernemingsgroei: Implicaties van Veranderende Bedrijfsprocessen voor de Management Accountant, Maandblad voor Accountancy en Bedrijfseconomie vol. 74(11), 484-491 